\title{
AKTIVITAS AGEN PENCERAH KULIT DARI KATEKIN SECARA IN SILICO
}

\author{
N. K. M. Giantari ${ }^{1 *}$, I W. I. Prayoga ${ }^{2}$ dan N. P. L. Laksmiani ${ }^{1}$

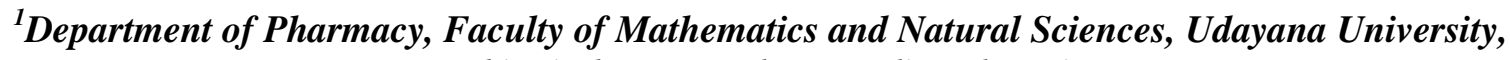 \\ Bukit Jimbaran, Badung, Bali, Indonesia \\ ${ }^{2}$ Central Laboratory of Universitas Udayana, Bukit Jimbaran, Badung, Bali, Indonesia \\ *e-mail: dewigiantari@yahoo.com
}

\begin{abstract}
ABSTRAK
Penggelapan warna kulit terjadi akibat produksi melanin yang berlebih pada kulit dapat disebabkan karena peningkatan aktivitas enzim tyrosinase related protein 1. Katekin merupakan senyawa golongan flavonoid yang memiliki kandungan antioksidan. Penelitian ini bertujuan untuk mengetahui afinitas dan mekanisme katekin sebagai agen pencerah kulit melalui penghambatan protein target tyrosinase related protein 1 secara in silico dengan menggunakan metode molecular docking. Penelitian dilakukan secara eksploratif dengan tahapan penyiapan database struktur 3D katekin dan protein tyrosinase related protein 1, optimasi struktur 3D katekin, preparasi protein, validasi metode molecular docking, serta docking katekin pada protein tyrosinase related protein 1. Hasil docking dinilai dari energi ikatan dan ikatan hidrogen yang terbentuk antara katekin dengan protein. Semakin kecil nilai energi ikatan maka ikatan antara katekin dengan protein semakin kuat dan stabil. Hasil penelitian menunjukkan bahwa katekin memiliki aktivitas sebagai agen pencerah kulit karena mampu menghambat protein tyrosinase related protein 1 dengan nilai energi ikatan yaitu $-6,35 \mathrm{kkal} / \mathrm{mol}$. Nilai energi ikatan katekin dengan protein tyrosinase related protein 1 lebih kecil dibandingkan dengan protein tyrosinase related protein 1 dengan native ligand-nya. Hal ini menunjukkan bahwa katekin memiliki potensi dan afinitas yang lebih besar dalam menghambat enzim tyrosinase related protein 1 dengan ikatan hidrogen pada asam amino yaitu ARG374. Berdasarkan hasil yang diperoleh, katekin memiliki aktivitas sebagai agen pencerah kulit dengan mekanisme menghambat enzim tyrosinase related protein 1 sehingga jumlah eumelanin yang terbentuk semakin sedikit dan kulit menjadi lebih cerah.
\end{abstract}

Kata kunci : katekin, pencerah kulit, tyrosinase related protein 1, in silico, molecular docking

\begin{abstract}
Darkening of the skin results from excessive production of melanin in the skin caused by an increase in tyrosinase related protein 1 enzyme activity. Catechins are flavonoid compounds which contain antioxidants. This study aims to determine the affinity and mechanism of catechins as skin lightening agents by inhibiting tyrosinase related protein 1 target proteins in silico using molecular docking methods. The study was carried out exploratively with the stages of preparing a database of 3D structures of catechins and tyrosinase related protein 1 , optimization of 3D structure of catechins, protein preparation, validation of molecular docking methods, and docking of catechins in tyrosinase related protein 1. Docking results are assessed from the bonding energy and hydrogen bonds formed between catechins and proteins. The smaller the bond energy value, the stronger the bond between the catechins and proteins. The results showed that catechins had activity as skin lightening agents because they were able to inhibit the tyrosinase related protein 1 with a bond energy value of $-6,35 \mathrm{Kcal} / \mathrm{mol}$. The energy value of the catechin bond with the tyrosinase related protein 1 is smaller than the tyrosinase related protein 1 with its native ligand. This shows that catechins have greater potential and affinity in inhibiting the tyrosinase related protein 1 enzyme with hydrogen bonds on amino acid residues, namely ARG374. Based on the results obtained, catechins have activity as skin lightening agents with the mechanism of inhibiting the tyrosinase related protein 1 enzyme so that the amount of eumelanin formed is less and the skin becomes brighter.
\end{abstract}

Key words: catechins, skin lightening, tyrosinase related protein 1, in silico, molecular docking

\section{PENDAHULUAN}

Indonesia merupakan negara tropis yang penuh dengan limpahan sinar matahari sepanjang tahunnya. Sinar matahari dapat memancarkan berbagai macam sinar baik yang dapat dilihat (visibel) maupun yang tidak dapat dilihat oleh mata. Sinar matahari yang dapat dilihat adalah sinar yang dipancarkan pada panjang gelombang lebih dari $400 \mathrm{~nm}$, sedangkan sinar matahari yang tidak dapat dilihat adalah sinar yang dipancarkan pada 
panjang gelombang $100 \mathrm{~nm}-400 \mathrm{~nm}$ yang disebut sinar ultraviolet (UV). Adanya sinar UV dapat bermanfaat untuk manusia yaitu mensintesa vitamin D dan membunuh bakteri. Namun disisi lain, sinar UV dapat berefek buruk pada manusia apabila terpapar pada kulit dalam waktu yang lama (Isfardiyana dan Safitri, 2014).

Paparan sinar UV pada kulit yang terlalu lama akan menyebabkan terjadinya gangguan pada kulit (Isfardiyana dan Sita, 2014). Kulit secara alami akan membentuk melanin yang berfungsi untuk melindungi kulit dari efek buruk radiasi UV. Namun adanya paparan sinar UV yang berlebihan akan mengakibatkan peningkatan sintesis melanin pada kulit (Salono et al., 2006; Mahardika, 2012). Peningkatan sintesis melanin pada kulit menyebabkan kulit menjadi berwarna gelap (Lynde dkk., 2006). Banyak cara dilakukan untuk membuat kulit gelap menjadi lebih cerah salah satunya dengan menghambat proses pembentukan melanin dalam tubuh (Lloyd et al., 2011).

Tyrosinase related protein 1 merupakan enzim utama yang berperan untuk katalisis berbagai tahap biosintesis melanin yaitu oksidasi asam amino L-tirosin menjadi 3,4 dihydroxyphenylalanine (L-DOPA) dan selanjutnya dioksidasi menjadi dopakuinon (Hindritiani dkk., 2013). Dopakuinon diubah menjadi dopakrom kemudian diubah menjadi 5,6 dihidroksi indole-2-carboxy acid (DHICA) oleh enzim D-dopachrome tautomerase. DHICA selanjutnya diubah oleh enzim tyrosinase related protein 1 menjadi Indole5,6-quinone carboxylic acid yang akan membentuk eumelanin yaitu melanin yang berwarna cokelat. Penghambatan enzim tyrosinase related protein 1 ini akan mencerahkan kulit dengan cara mengurangi efek penggelapan kulit (Laksmiani and Nugraha, 2019).

Senyawa alam yang memiliki khasiat sebagai antioksidan memiliki peranan penting dalam mencegah terjadinya pembentukan melanin yang berlebih pada tubuh. Diperlukan suatu pengembangan terapi sebagai agen pencerah kulit, salah satunya dengan eksplorasi potensi bahan alam berkhasiat. Katekin merupakan senyawa golongan flavonoid yang mengandung antioksidan. Katekin memiliki peranan dalam penurunan produksi melanin yang berlebih di dalam tubuh melalui penghambatan enzim tirosinase secara in vitro dan in vivo (Khan et al., 2013).

Pengujian terhadap potensi katekin sebagai agen pencerah kulit dapat dilakukan dengan mengetahui afinitas dan mekanisme molekuler dari katekin terhadap protein target enzim tyrosinase related protein 1 dengan menggunakan metode molecular docking. Molecular docking merupakan teknik kimia komputasi yang dapat digunakan untuk mempercepat pemilihan senyawa yang akan diisolasi dan disintesis dengan mengidentifikasi dan optimasi senyawa penuntun dalam proses penemuan obat dengan menggunakan pemodelan komputer (in silico). Oleh karena itu, potensi katekin dalam menghambat enzim tyrosinase related protein 1 dapat diketahui.

\section{BAHAN DAN METODE}

\section{Bahan}

Struktur senyawa katekin dalam bentuk 3 dimensi yang diunduh pada website https://pubchem.ncbi.nlm.nih.gov/. Struktur protein target enzim tyrosinase related protein 1 (PDB ID: 5M8M) yang diunduh pada website PDB (protein data bank) yaitu http://www.rcsb.org/pdb/home/home.do.

\begin{abstract}
Alat
Seperangkat komputer dengan spesifikasi Windows 1064 bit yang dilengkapi program Hyperchem 8, Chimera 1.10.1 dan aplikasi AutoDock Tools yang dilengkapi program Autodock 4.2 dan Autogrid.
\end{abstract}

\section{Metode Penelitian}

\section{Optimasi Senyawa Katekin 3 Dimensi}

Struktur senyawa katekin dalam bentuk 3 dimensi dioptimasi menggunakan program Hyperchem 8. Optimasi dilakukan dengan metode komputasi semi-empiris AM1 (Austin Model 1) dengan tahapan yaitu kalkulasi single point dan optimasi geometri (Laksmiani and Nugraha, 2019).

\section{Preparasi Protein Target}

Preparasi protein dilakukan menggunakan program Chimera 1.10.1 dengan memisahkan struktur 3 dimensi protein tyrosinase related protein 1 dengan native ligand-nya (Laksmiani and Nugraha, 2019). 


\section{Validasi Metode Molecular Docking}

Validasi metode molecular docking dilakukan dengan men-docking-kan kembali (redocking) native ligand pada protein tyrosinase related protein 1 yang sudah dihilangkan native ligand-nya menggunakan aplikasi Autodock Tools (Autodock 4.2 dan Autogrid). Parameter validasi metode adalah Root Mean Square Deviation (RMSD). RMSD yang dapat diterima adalah $\leq 3,0 \AA$ (Laksmiani and Nugraha, 2019).

\section{Docking Katekin pada Protein Tyrosinase Related Protein 1}

Senyawa katekin yang telah dioptimasi didocking-kan pada protein tyrosinase related protein 1 yang sudah dihilangkan native ligand-nya menggunakan aplikasi Autodock Tools dengan tahapan docking yang sama seperti pada validasi metode. Hasil analisis menunjukkan konformasi ikatan senyawa pada protein dengan nilai energi ikatan dan ikatan hidrogen yang terbentuk (Laksmiani and Nugraha, 2019).

\section{Analisa Data}

Hasil molecular docking adalah energi ikatan dan ikatan hidrogen yang terbentuk. Jenis ikatan hidrogen yang terbentuk digunakan untuk menganalisis mekanisme interaksi yang terbentuk. Energi ikatan digunakan untuk menunjukkan kekuatan ikatan antara senyawa dengan protein. Semakin rendah nilai energi ikatan, maka ikatannya semakin kuat dan stabil (Laksmiani and Nugraha, 2019).

\section{HASIL DAN PEMBAHASAN}

\section{Optimasi Struktur Senyawa Katekin 3 Dimensi}

Struktur katekin dalam bentuk 3 dimensi yang telah diunduh dilakukan optimasi dengan program Hyperchem 8 dengan metode komputasi semi empiris AM1. Tahapan optimasi yaitu dilakukan kalkulasi single point dan optimasi geometri untuk mendapatkan struktur senyawa katekin yang paling stabil yang ditandai dengan energi total hasil optimasi geometri lebih kecil dibandingkan energi total hasil kalkulasi single point. Pada proses optimasi geometri, energi total molekul diminimalisasi sehingga senyawa menjadi lebih stabil. Hasil optimasi senyawa katekin ditunjukkan pada Gambar 1.

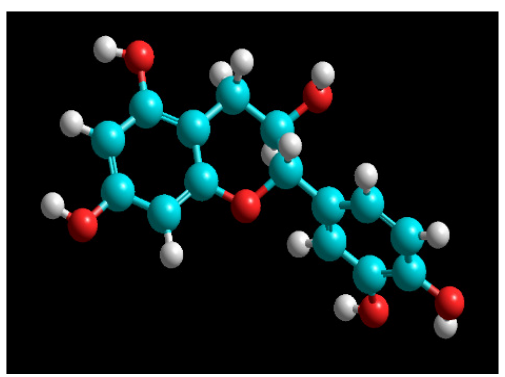

Gambar 1. Hasil Optimasi Struktur 3 Dimensi Senyawa Katekin.

Besar energi total hasil kalkulasi single point dan optimasi geometri yang diperoleh dari senyawa katekin berturut-turut yaitu $3855,124434 \mathrm{kkal} / \mathrm{mol}$ dan $-3861,9814$ $\mathrm{kkal} / \mathrm{mol}$. Berdasarkan hasil tersebut, struktur katekin telah stabil sehingga diperoleh struktur katekin yang telah teroptimasi.

\section{Preparasi Protein Tyrosinase Related Protein 1}

Protein tyrosinase related protein 1 dipreparasi menggunakan program Chimera 1.10.1 dengan memisahkan protein dengan native ligand-nya sehingga diperoleh struktur protein tanpa native ligand dan struktur native ligand yang terpisah seperti gambar 2 . Pemisahan protein dengan native ligand bertujuan untuk menyediakan pocket yang akan digunakan untuk tempat senyawa uji berikatan dengan protein tyrosinase related protein 1. Rantai protein yang dipilih dalam pengujian ini adalah rantai A yang berikatan dengan native ligand 0TR (Tropolone), yang mana 0TR berfungsi sebagai inhibitor protein tyrosinase related protein 1 (Ismaya et al., 2011).

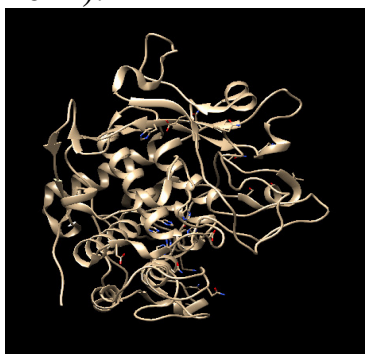

(a)

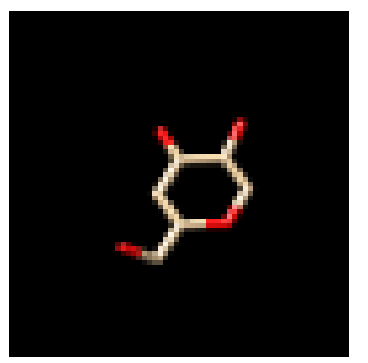

(b)
Gambar 2. Struktur 3 Dimensi Protein Tyrosinase Related Protein 1 tanpa ligan (a) dan native ligand protein tyrosinase related protein 1 (b).

\section{Validasi Metode Molecular Docking}

Validasi metode molecular docking dilakukan menggunakan aplikasi Autodock 
Tools dengan melakukan penambatan ulang (redocking) native ligand protein tyrosinase related protein 1 dengan protein tyrosinase related protein 1 yang sudah dipreparasi yaitu sudah dihilangkan native ligand-nya. Parameter validasi metode adalah nilai RMSD. RMSD merupakan nilai penyimpangan dari posisi ikatan native ligand dengan protein setelah di-docking-kan terhadap posisi ikatan native ligand yang sebenarnya. Semakin besar nilai RMSD maka semakin besar penyimpangan yang menunjukkan semakin besar kesalahan prediksi interaksi ligan dengan protein, sedangkan semakin kecil nilai RMSD maka menunjukkan bahwa posisi ligan yang diprediksi semakin baik karena semakin mendekati konformasi native ligand yang sebenarnya (Nauli, 2014). Nilai RMSD yang diperoleh pada penelitian ini adalah 2,33 $\AA$ yang berarti bahwa metode molecular docking yang digunakan telah memenuhi persyaratan yang ditetapkan dan telah tervalidasi. Visualisasi interaksi validasi metode molecular docking dapat dilihat pada Gambar 3.

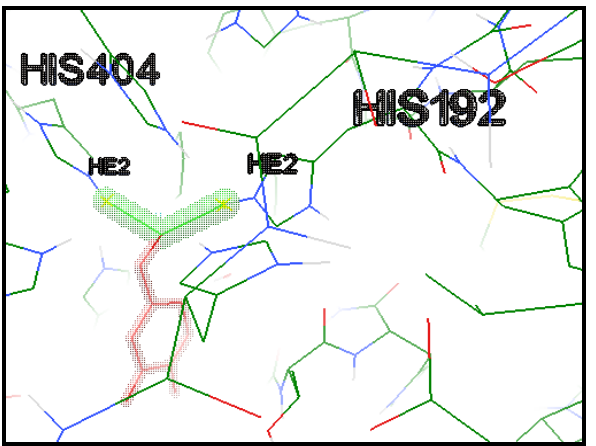

Gambar 3. Visualisasi interaksi protein tyrosinase related protein 1 dengan native ligand-nya.

\section{Docking Katekin pada Protein Target}

Docking senyawa katekin yang telah dioptimasi pada protein tyrosinase related protein 1 dilakukan menggunakan aplikasi Autodock Tools dengan koordinat yang sama seperti pada validasi metode yang telah tervalidasi. Berdasarkan hasil docking, diperoleh 10 konformasi ikatan antara katekin dengan protein tyrosinase related protein 1 , yang mana dari 10 konformasi tersebut dipilih satu konformasi dengan nilai energi ikatan terendah yang menunjukkan ikatan yang paling stabil. Hasil docking antara katekin dengan protein tyrosinase related protein 1 yang ditunjukkan pada tabel 1 menunjukkan bahwa energi ikatan antara katekin dengan protein tyrosinase related protein 1 bernilai negatif yaitu $-6,35 \mathrm{kkal} / \mathrm{mol}$. Hal ini berarti senyawa katekin mampu berinteraksi dengan protein tyrosinase related protein 1 dan membentuk ikatan pada protein target. Protein tyrosinase related protein 1 menunjukkan afinitas dengan ikatan hidrogen pada residu asam amino ARG374 yang terbentuk melalui gugus HE dan $\mathrm{HH} 21$ pada protein dengan gugus $\mathrm{O}$ pada katekin yang tergambar pada visualisasi docking katekin dengan protein tyrosinase related protein 1 pada gambar 4 . Berdasarkan hasil yang diperoleh katekin berpotensi sebagai agen pencerah kulit dengan mencegah proses pembentukan melanin yang berlebih pada tubuh dengan penghambatan enzim tyrosinase related protein 1 melalui pembentukan ikatan hidrogen dengan afinitas yang ditunjukkan oleh energi ikatan yang dihasilkan bernilai negatif.

Tabel 1. Hasil Docking Katekin dengan Protein Tyrosinase related Protein 1

\begin{tabular}{|c|c|c|c|}
\hline $\begin{array}{c}\text { Protein } \\
\text { Target }\end{array}$ & Ligan & $\begin{array}{c}\text { Energi } \\
\text { Ikatan } \\
(\mathrm{kkal} / \mathrm{mol})\end{array}$ & $\begin{array}{c}\text { Ikatan } \\
\text { Hidrogen }\end{array}$ \\
\hline \multirow{2}{*}{$\begin{array}{l}\text { Tyrosinase } \\
\text { related } \\
\text { protein } 1\end{array}$} & $\begin{array}{l}\text { Native } \\
\text { ligand }\end{array}$ & $-5,39$ & $\begin{array}{l}\text { HIS192 } \\
\text { HIS404 }\end{array}$ \\
\hline & Katekin & $-6,35$ & $\begin{array}{l}\text { ARG374 } \\
\text { ARG374 }\end{array}$ \\
\hline
\end{tabular}

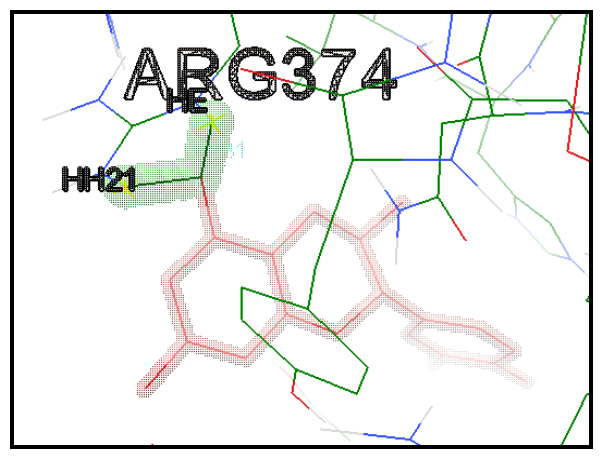

Gambar 4. Visualisasi Interaksi Hasil Docking Katekin pada Protein Tyrosinase related protein 1 .

\section{KESIMPULAN}

Katekin memiliki afinitas terhadap protein tyrosinase related protein 1 yang ditunjukkan dengan energi ikatan yang dihasilkan yaitu $6,35 \mathrm{kkal} / \mathrm{mol}$, hal ini berarti katekin berpotensi sebagai agen pencerah kulit dengan mencegah proses pembentukan melanin yang berlebih pada tubuh dengan penghambatan protein 
tyrosinase related protein 1 melalui pembentukan ikatan hidrogen pada protein tersebut.

\section{UCAPAN TERIMA KASIH}

Penulis mengucapkan terima kasih kepada dosen-dosen pembiming, keluarga, temanteman, dan semua pihak yang telah membantu dan mendukung dalam penelitian ini.

\section{DAFTAR PUSTAKA}

Hindritianti, R., Dhianawaty, D., Sujatno, M., Sutedja, E., dan Setiawan. 2013. Penurunan Aktivitas Tirosinase dan Jumlah Melanin oleh Fraksi Etil Asetat Buah Malaka (Phyllantus emblica) pada Mouse Melanoma B16 Cell-Line. MKB, 42: 118-124.

Isfardiyana, S. H., dan Safitri, S. R. 2014. Pentingnya Melindungi Kulit dari Sinar Ultraviolet dan Cara Melindungi Kulit dengan Sunblock Buatan Sendiri. Jurnal Inovasi dan Kewirausahaan, 3: 126-133.

Ismaya, W. T., Rozeboom, H. J., Weijn, A., Mes, J. J., Fusetti, F., Wichers, H. J., and Dijkstra, B. W. 2011. Crystal Structure of Agaricus bisporus Mushroom Tyrosinase: Identity of the Tetramer Subunits and Interaction with Tropolone. Biochemistry, 50: 5477-5486.
Khan, B.A., Akhtar, N., Hussain, I., Abbas, K.A. and Rasul, A. 2013. Whitening Efficacy of Plant Extracts Including Hippophae rhamnoides and Cassia fistula Extracts on the Skin of Asian Patients with Melasma. Postepy Dermatologii Alergologii, 15: 226-232.

Laksmiani N. P. L and Nugraha I. P. W. 2019. Depigmentation Activity of Secang (Caesalpinia Sappan L.) Extract Through Tyrosinase, Tyrosinase Related Protein-1 and Dopachrome Tautomerase Inhibition. Biomed Pharmacol J, 12(2).

Lloyd, H. W., Jenna, N. and Kammer, B. A. 2011. Treatment of Hyperpigmentation. Semin Cutan Med Surg, 30: 171-175.

Lynde, C. B., Kraft, J. N. and Lynde, C. W. 2006. Topical Treatments for Melasma and Postinflammatory Hyperpigmentation. Skin Therapy Letter, 11: 1-12.

Mahardika, H. 2012, Uji Penghambatan Tirosinase Secara In Vitro Serta Stabilitas Fisik dan Stabilitas Kimia Sediaan Krim yang Mengandung Asam Azelat, Skripsi. S. Farm, Fakultas Matematika dan Ilmu Pengetahuan, Universitas Indonesia, Depok.

Nauli, T. 2014, Penentuan Sisi Aktif Selulase Aspergillus Niger dengan Docking Ligan. JKTI, 16. 